\title{
Researches On The Problems And Solutions Of SME Financing Status Quo
}

\author{
Li guanyue \\ jonkoping university \\ Gjuterigatan 5,P.O. Box 1026 SE-551 11 Jonkoping
}

\begin{abstract}
The medium and small enterprise plays an irreplaceable role in China's national economy, but harsh financing environment seriously restricts and even endangers the survival and development of medium and small enterprises. First, this article introduces the status and characteristics of SME financing. Second, analyzes the channels and the difficulties of SME financing in our country. Finally, comes up with some measures to ease difficulties of SME financing. In this article, the research on the problems and solutions of SME financing status quo has a certain significance and guiding value.
\end{abstract}

\section{Keywords-SME, Financing, The Analysis Of Countermeasures}

\section{THE STATUS QUO OF CHINA'S SME}

\section{A. The development and current situation of SME}

No matter in developed countries or in developing countries, the small and medium-sized enterprise is the important support of national economy in the development of a country. Small and medium-sized enterprises play an irreplaceable role in improving the national economic production, promoting the progress of science and technology, increasing employment, expanding exports, etc. After China carried out reform and open policy, our national small and mediumsized enterprises have developed very quickly, and the contribution rate of them to national economy have raised constantly. As of May 2011, the number of small and medium-sized enterprises in China has more than 40 million, and has taken up more than $99 \%$ of all enterprises. Total imports and exports of small and medium-sized enterprises have accounted for $69 \%$. The gross industrial output value, sales income, taxes of SME have respectively accounted for $60 \%$ of the total, $57 \%$ and $50 \%$. Small and medium-sized enterprises mostly engage in those jobs in the third industry, which are close to the market, close to the user. They are active in the most competitive areas of the market. SME is the main body of market economy and the micro foundation of market system. Because the cost of entrepreneurship and management of small and medium enterprises are relatively low, and the resilience of the SME market is strong, SME is the main place to employment. Small and medium-sized enterprises have provided nearly $80 \%$ of jobs for the society nowadays.

\section{B. The main characteristics of SME}

At present, small and medium-sized enterprises in our country are mainly private enterprises, and have already formed the situation of state-owned enterprises and private enterprises in two forms coexist. As for industrial enterprises, for example, state-owned enterprises have accounted for only $15 \%$ of the total, private enterprises have accounted for $85 \%$. The development of SME is mainly concentrated on the labor-intensive industries. The employment capacity and employment investment elasticity of SME are significantly higher than large enterprises. According to statistics, in terms of resettlement workers, SME is nearly double higher than large enterprises. China is a large country, the distribution of SME in different regions is extremely uneven. According to statistics, the number of small and medium-sized enterprises in eastern and central each accounts for $42 \%$ of the total in China and the west accounts for $15 \%$. This suggests that in the enterprise scale, the average output value of small and medium-sized enterprises in eastern is larger than the central and western. In the process of reform, compared with large enterprises, small and medium-sized enterprises are often the experimental zone and the breakthrough. Various results of the reform of small and medium-sized enterprises can provide some useful experiences for the reform practice of large enterprises.

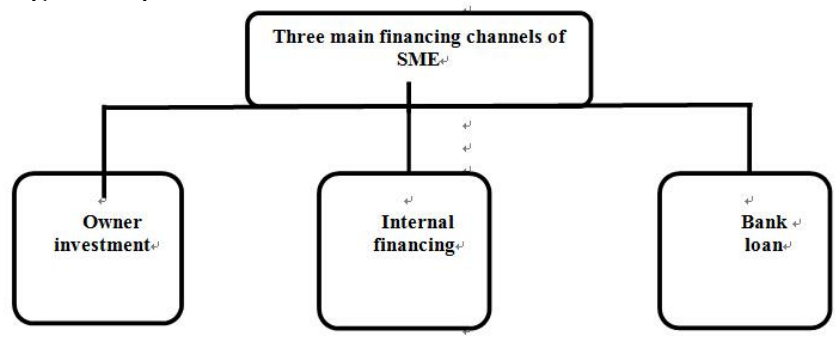

Figure 1: Three main financing channels of SME

\section{THE CHANNELS AND DIFFICULTIES OF SME FINANCING IN OUR COUNTRY}

\section{A. The major financing ways of SME}

At present, the financing channel of small and mediumsized enterprises is relatively narrow. The owner investment, internal financing and bank loan are the main financing channels of small and medium-sized enterprises. However, most of financing channels blocked, small and medium-sized enterprises do not have much practical significance. According to the sources of corporate funding, corporate finance can be divided into endogenous and exogenous financing two major types of financing.

1) Endogenous financing

Equity financing and debt financing are two ways of the endogenous financing. The capital formation of endogenous financing has show the primitiveness, autonomy and other characteristics. Endogenous financing is the indispensable important component of the survival and development of small and medium-sized enterprises. However, small and 
medium-sized enterprises general have insufficient funds, and the self accumulation is limited.

2) Exogenous financing

Exogenous Financing refers to the use of corporate funds to external financing mainly in direct financing and indirect financing in two ways. As we know, stock, enterprise bond and the loan to bank are three kinds of main financing ways of the enterprise outside, also are the intrinsic foundation of capital market structure. However, the difficulty of obtaining external financing is always one of the problems that restrict the development of MES.

3) The relation between the two major types of financing

As Chinese small and medium-sized enterprises are developing from the stage of starting to growing, stead of continue to depending on internal financing, small and medium-sized enterprises start to look for exogenous financing. Since 1949, in direct financing system has played the dominating role in our financing system, so it is very important to the development of small and medium-sized enterprises.

\section{B. The problems of SME financing}

The capital requirements are expected to increase rapidly with the continuous development of the small and mediumsized enterprises scale. From the point of capital requirements, compared with large enterprises, the demand for a single enterprise fund is not large. However, there is a difficulty in financing in small and medium-sized enterprises of our country, lack of capital has greatly limited the development of small and medium-sized enterprises of our country. Mainly displays in:

$$
\text { 1) It has }
$$

become

increasingly difficult to obtain bank loans.

It has become hard for banks, even healthy ones, to find finance; large companies with healthy cash flows have also been cut off from all but the shortest-term financing. Due to the small and medium-sized enterprise is difficult to meet the mortgage guarantee conditions of bank loans and the loan risk is bigger, the enthusiasm of bank lending is generally not high. According to incomplete statistics, small and medium-sized enterprises can obtain loans from the bank account for only $8 \%$ of the total credit.

2) Enterprise scale limits the financing from capital market.

At present, our country capital market is still very imperfect, most enterprises, especially small and medium-sized enterprises are difficult to obtain funds through direct financing channels. Limited by the scale, managing experience and level, small and medium-sized enterprises cannot obtain bank loan and these above-mentioned directly affect financing capacity.

3) Small and medium-sized enterprises lack of credit and the credit reporting system is not perfect.

Due to the information asymmetry in the credit finance market, factors like low credit will and insufficient credit become major reasons constraining the scale of SME financing. Our country's experience in credit system construction indicates that credit information sharing problems have become the bottleneck of China's further constructing corporate credit system.

4) The development of the credit guarantee and the small loan company is nonstandard.

In recent years, the guarantee company and the small loan company are developing rapidly, which the main clients are small and medium-sized enterprises. However, the overall scale of these institutions is small, strength is weak, resist risk ability is not strong, business management is not standard and the financing cost is higher. As for small and medium-sized enterprises, their financing through the credit guarantee and the small loan company become helpless choice.

5) Their own problems.

The small and medium-sized enterprise itself also has some problems and deficiencies: first, some defects exist in the administration system. Secondly, Chinese small and medium-sized enterprise oneself is integrated ability is low, and competition ability is not strong. Thirdly, industry personnel quality is not high. The management problem of the business enterprise only is resolved by enterprise governor themselves.

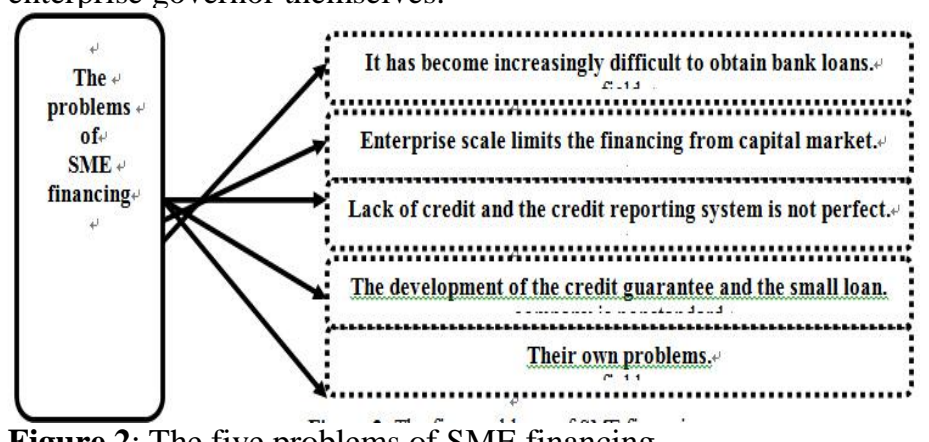

Figure 2: The five problems of SMË financing.

III. THE COUNTERMEASURES TO RESOLVE THE DIFFICULTIES OF SME FINANCING

\section{A. To further improve the support of SME financial laws and regulations}

China's small and medium-sized enterprise ownership structure is more complex, it is not good for the faster development of SME. With the implementation of SME Promotion Law, the SME subject legal system will be perfected. In short, the implementation of SME Promotion Law will greatly benefit the development of SME in China. At the same time, in order to provide legal protection for SME financing, the authorities should further improve the support of SME financial laws and regulations.

\section{B. To strengthen the construction of SME credit system}

Construction of credit information system is of important significance for resolving the difficulties of SME financing. In present China, the law about credit investigating is absent and the construction of credit investigating model is very important. In the construction of the small and medium-sized enterprise credit system, the government should not blindly emphasize the role of banks, and should mobilize the 
enthusiasm and obligations of banks, enterprises and related departments. Therefore, the establishment of credit system should be led by the government, banks as the main body, and liaise with other departments to build together.

\section{To further improve SME financial support system}

The government should have been positively taking all kinds of measures to improve the financial support system and promote the technology innovation of small and mediumsized enterprises. Our financial support policies are being improved, a sound credit guarantee system installed and market access eased for the benefit of SME development. For example, the government should encourage commercial banks to develop financial products to adapt to the development of small and medium-sized enterprises. In short, the establishment of an efficient financial support system is of significance for the development and innovation of those enterprises and for the economic development.

\section{REFERENCES}

[1] XU Qin, XU Xiang Xiang. SME financing situation and countermeasures - based in Hubei province, Shandong province, and SME questionnaire comparative analysis $[\mathrm{J}]$ Contemporary Economic,2012,24:48-49.

[2] ZHOU Ling Lan. The status, problems and countermeasures of SME financing in Zhejiang Province [J]. Economist,2006,02:274-275.

[3] ZONG Song, LI Xiao Jun. SME financing problems and countermeasures -. Summary researches [J] Economic Research Guide,2012,01:66-68.

[4] LI Yi. The status quo and recommendations of China's SME financing $[\mathrm{J}]$. Cooperation in the economic and technological,2012,03:66-67.

[5] HAN Yu Da, TANG Zhi Gang, KE Xiao Wei. The situations and countermeasures of SME financing - Based on the Wenzhou area [J] Zhejiang Financial,2010,09:41-43.

[6] GUAN Wei Qi, HU Yu Jie. The situations and countermeasures of SME financing in Gansu province [J]. Hebei Agricultural Sciences,2010,12:131-133. 